\title{
EXTRACTION OF CHITIN AND CHITOSAN FROM MUD CRAB SCYLLA TRANQUEBARICA (FABRICIUS, 1798)
}

\author{
N.Thirunavukkarasu ${ }^{1}$, A.Shanmugam ${ }^{2}$ \\ 'Department of Marine Studies and Coastal Resource Management, Madras Christian College, \\ Tambaram, Chennai, Tamilnadu, India. \\ ${ }^{2}$ Centre of Advanced Study in Marine Biology, Annamalai University, Parangipettai, Tamilnadu, India. \\ E-mail : thirush2k3@yahoo.co.in
}

\begin{abstract}
Chitin is a polysaccharide of animal origin, is obtained from waste material of seafood industries. It occurs in the skeletal material of crustaceans such as crabs, shrimps, lobsters, prawns and crayfish. The extraction of the chitin and chitosan of various body parts of mud crab Scylla tranquebarica showed that the legs shell yield more than carapace shell and claw shell. The quality parameters of chitin \& chitosan was analysed by Fourier Transform Infrared (FT-IR) Spectrometry and compared with standards.
\end{abstract}

KEYWORDS: Chitin, chitosan, mud crab, Scylla tranquebarica, FT-IR.

\section{INTRODUCTION}

Chitin is a poly - B - (1-4) - N - acetyl -D-glucosamine. It is a nitrogen containing polysaccharide, related chemically to the cellulose. Chitin is the second most abundant natural polymer, after cellulose. Like cellulose, it is a polysaccharide - a compound formed of many identical simple sugar molecules. Chitin was first found in mushrooms in 1811 by Professor Henri Braconnot, Director of the Botanical Gardens at the Academy of Sciences in Nancy, France.

The crustacean processing industries over the world turn out more than 60,000 tonnes of waste every year. The head and shell of crustaceans such as prawn, lobster, crab, squilla, krill etc. form the waste. The crustacean wastes contain about $10 \%$ of chitin on dry weight basis. The proper utilization of these shell wastes not only solves the problem of their disposal but also forms the basis for many potential products used in the fields such as textiles, photography, medicine, agriculture, food processing etc. The global attention on the importance of chitin and chitosan has been demonstrated in three International conferences on chitin and chitosan held in the years 1977 , 1982 and 1985 (Udgata et al., 1994).

Ministry of Health and Welfare, Japan has approved chitin, chitosan and their derivatives as food additives. In India, chitin has been found to promote growth in broiler chicks. Incorporation of chitin in poultry feed at a level of 0.5 percent decreases the food consumption ratio and increases the body weight by 12 percent in comparison with chicks fed on a chitin-free diet (Brzerki, 1987). The Central Institute of Fisheries Technology (CIFT), Cochin conducted experiment on chicken that was fed with chitin-incorporated diet. The results showed $10-12 \%$ increase in the chicken than fed with the normal feed (Patel and Sadam, 2002).

The chitin with calcium combination decolorise waste products and hence the crab shells were used as wastewater filters for textile industries in USA (Krishnamoorthy et al, 2003). Chitosan can adhere on to plastics, rubber, glass and cellulose and thus might have value in the manufacture of adhesives. Besides the above, the chitin and chitosan have been applied in the formulation of cosmetics (Brzeski, 1987). A novel bioinorganic bone implant containing deglued bone using chitosan and gelatin was also been described by Saraswathi et al, 2001.

Because of the above importance of chitin and chitosan, the present study has been aimed with the following objectives

- To isolate the chitin and chitosan from the carapace and exoskeleton of claw and legs of $S$. tranquebarica.

- To quantify the yield of chitin and chitosan

- To check the chitin and chitosan extracted from the shell of S.tranquebarica with standard chitin and chitosan through FT-IR spectral analysis.

\section{MATERIALS AND METHODS}

The chitin was extracted from the shells of following the method of Takiguchi 1991a using hydrochloric acid and sodium hydroxide by demineralization and deprotenisation. Further the chitosan was obtained by acetylating the chitin following the methodology of Takiguchi $1991 \mathrm{~b}$ by deacetylation. The quality parameters of chitin \& chitosan was analysed by Fourier Transform Infrared (FT-IR) Spectrometry by the method given by Shigemasa et al, 1996. FT-IR spectroscopy of solid samples of chitin and chitosan relied on a Bio-Rad FTIS-40 model, USA. Sample $(10 \mu \mathrm{g})$ was mixed with $100 \mu \mathrm{g}$ of dried Potassium Bromide $(\mathrm{KBr})$ and compressed to prepare a salt disc (10mm diameter).

\section{RESULTS}

The yield of chitin and chitosan from the shell of mud crab S. tranquebarica in different body parts are presented in 
Table. 1. In the present study, the yield of chitin was found more in the shell of legs than that of carapace and claw i.e., $20 \mathrm{~g}$ of the shell yielded $2.148 \mathrm{~g}, 1.582 \mathrm{~g}$ and $2.924 \mathrm{~g}$ of chitin representing $10.74 \%, 7.91 \%$ and $14.62 \%$ respectively in the shell of carapace, claw and legs. Whereas the yield of chitosan was more in the shell of legs than that of carapace and claw. The chitosan yield was recorded as $1.318 \mathrm{~g}$, $0.824 \mathrm{~g}$ and $1.684 \mathrm{~g}$ representing $6.59 \%, 4.12 \%$ and $8.42 \%$ respectively in the shell of carapace, claw and legs.

Table 1. The yield of chitin \& chitosan from the shell of different body parts of

\begin{tabular}{|c|c|c|c|c|}
\hline Body part & $\begin{array}{c}\text { Chitin } \\
\text { Yield(g) }\end{array}$ & $\begin{array}{c}\text { Yield } \\
(\mathbf{\%})\end{array}$ & $\begin{array}{c}\text { Chitosan } \\
\text { Yield (g) }\end{array}$ & $\begin{array}{c}\text { Yield } \\
(\%)\end{array}$ \\
\hline Carapace & 2.148 & 10.74 & 1.318 & 6.59 \\
\hline Claw & 1.582 & 7.91 & 0.824 & 4.12 \\
\hline Legs & 2.924 & 14.62 & 1.684 & 8.42 \\
\hline
\end{tabular}

\section{S. tranquebarica}

\section{FT-IR}

The FT-IR spectrum of the chitin and chitosan isolated from the carapace and shell of the claw and legs of $S$. tranquebarica were compared with the standard chitin and chitosan. The IR spectrum of the standard chitin contains 17 major peaks (Fig. 1); whereas the IR spectrum of the sample of carapace (Fig. 2), claw (Fig. 3) and legs (Fig. 4) recorded 16 peaks and the major peaks were compared with the standard chitin in the Table. 2. The IR spectrum of the standard chitosan contains 15 major peaks (Fig. 5) whereas the IR spectrum of the sample of carapace (Fig. 6), claw (Fig. 7) and legs (Fig. 8) also recorded 13 peaks and compared with the standard chitosan in the Table. 3.

Table 2. FT-IR spectral values $\left(\mathrm{cm}^{-1}\right)$ of standard chitin and different chitin samples from $S$. tranquebarica

\begin{tabular}{|c|c|c|c|c|}
\hline S.No. & $\begin{array}{c}\text { Standard chitin } \\
\left(\mathbf{c m}^{-1}\right)\end{array}$ & $\begin{array}{c}\text { Carapace } \\
\left(\mathbf{c m}^{-1}\right)\end{array}$ & $\begin{array}{c}\text { Claw } \\
\left(\mathbf{c m}^{-1}\right)\end{array}$ & $\begin{array}{c}\text { Legs } \\
\left(\mathbf{c m}^{-1}\right)\end{array}$ \\
\hline 1 & 530.11 & 529.80 & 529.70 & 531.34 \\
\hline 2 & 606.68 & 557.59 & 560.82 & 561.17 \\
\hline 3 & 690.99 & 696.93 & 693.56 & 692.54 \\
\hline 4 & 752.33 & - & - & - \\
\hline 5 & 896.28 & 895.86 & 895.70 & 896.02 \\
\hline 6 & 952.29 & 951.08 & 950.83 & 951.25 \\
\hline 7 & 1026.33 & 1024.16 & 1022.79 & 1024.03 \\
\hline 8 & 1073.93 & 1073.83 & 1074.21 & 1073.65 \\
\hline 9 & 1116.12 & 1117.39 & 1117.98 & 1117.29 \\
\hline 10 & 1156.92 & 1158.43 & 1158.68 & 1157.9 \\
\hline 11 & 1203.40 & 1203.94 & 1204.01 & 1203.94 \\
\hline 12 & 1259.94 & 1259.74 & 1259.88 & 1259.87 \\
\hline 13 & 1315.40 & 1316.97 & 1316.61 & 1316.43 \\
\hline 14 & 1377.38 & 1377.98 & 1378.07 & 1377.69 \\
\hline 15 & 1418.74 & 1420.45 & 1420.80 & 1419.15 \\
\hline 16 & 1563.42 & 1558.41 & 1558.09 & 1557.81 \\
\hline 17 & 1661.50 & 1661.42 & 1663.11 & $1661.05 \&$ \\
& & & & 1627.43 \\
\hline
\end{tabular}

Table 3. FT-IR spectral values $\left(\mathrm{cm}^{-1}\right)$ of standard chitin and different chitin samples from S. tranquebarica

\begin{tabular}{|c|c|c|c|c|}
\hline S.No. & $\begin{array}{c}\text { Standard chitosan } \\
\left(\mathbf{c m}^{-1}\right)\end{array}$ & $\begin{array}{c}\text { Carapace } \\
\left(\mathbf{c m}^{-1}\right)\end{array}$ & $\begin{array}{c}\text { Claw } \\
\left(\mathbf{c m}^{-1}\right)\end{array}$ & $\begin{array}{c}\text { Legs } \\
\left(\mathbf{c m}^{-1}\right)\end{array}$ \\
\hline 1 & 408.04 & 408.10 & 408.55 & 408.46 \\
\hline 2 & 431.06 & - & - & - \\
\hline 3 & 459.13 & - & - & - \\
\hline 4 & 570.60 & 531.38 & 528.02 & - \\
\hline 5 & 666.17 & 609.72 & 608.11 & 611.31 \\
\hline 6 & 897.41 & 896.31 & 896.41 & 896.63 \\
\hline 7 & 1026.63 & 1023.15 & 1022.58 & 1022.41 \\
\hline 8 & 1077.93 & 1074.73 & 1075.27 & 1075.25 \\
\hline 9 & 1154.64 & 1158.09 & 1158.86 & 1158.72 \\
\hline 10 & 1259.54 & 1259.99 & 1260.30 & 1260.20 \\
\hline 11 & 1324.24 & 1317.41 & 1321.21 & 1320.78 \\
\hline 12 & 1380.78 & 1378.54 & 1380.14 & 1379.92 \\
\hline 13 & 1422.73 & 1417.10 & 1418.55 & 1418.64 \\
\hline 14 & 1587.94 & 1571.21 & 1571.99 & 1571.53 \\
\hline 15 & 1660.55 & $1628.04 \&$ & 1665.48 & 1664.26 \\
& & 1662.64 & & \\
\hline
\end{tabular}

\section{DISCUSSION}

In the present investigation chitin isolated from the carapace and the shell of the claw and legs of $S$. tranquebarica was found to be $10.74 \%, 7.91 \%$ and $14.62 \%$ respectively. The content of chitin in crab shell varies depending on species as well as the body part within the same species. In supporting this $20.5 \%, 10.0 \%$ and $14.0 \%$ chitin in body shell, claw shell and legs shell of S. serrata (Nair and Madhavan, 1989) in which the chitin content of the leg shell agrees well with the value of the present study. Subasinghe (1999) also noticed more chitin yield in snow crab legs (32\%) than claws (24\%). The same trend also reported in the other portunids such as in $S$. serrata and $P$. pelagicus (Das et al, 1996), the yield of chitin was more in the shell of legs $(16.07 \%$ and $20.19 \%)$ than in body $(11.67 \%$ and $13.51 \%)$ and claw $(10.42 \%$ and $11.66 \%)$.

The chitosan yielded representing $6.59 \%, 4.12 \%$ and $8.42 \%$ respectively in the shell of carapace, claw and legs. The chitosan yield reported in the mantis shrimp Harpiosquilla melanoura from $4.4 \%$ to $8.3 \%$ in different size groups(Varghese, 2002).

The FT-IR peaks at $534.61 \mathrm{~cm}^{-1}, 1024.16 \mathrm{~cm}^{-1}$, $1321.88 \mathrm{~cm}^{-1}, 1380.81 \mathrm{~cm}^{-1}$, and $1640.40 \mathrm{~cm}^{-1}$ in chitin from the shell of Sepia aculeata, which resembling the peaks of crab carapace, legs and the claw. Whereas in the chitin sample of Loligo duvaucelli the peaks at $533.44 \mathrm{~cm}^{-1}$, $896.73 \mathrm{~cm}^{-1}, 1032.11 \mathrm{~cm}^{-1}, 1315.60 \mathrm{~cm}^{-1}, 1377.88 \mathrm{~cm}^{-1}$, $1561.36 \mathrm{~cm}^{-1}$ and $1657.29 \mathrm{~cm}^{-1}$ were also coincide with the same crabshell samples(Parasakthi, 2004).

The major absorption band between 1220 and 1020 $\mathrm{cm}^{-1}$ represents the free primary amino group $\left(-\mathrm{NH}_{2}\right)$ at $\mathrm{C}_{2}$ position of glucosamine, a major group present in chitosan (Saraswathi et al, 2001). Further the sample showed the absorption based for the free amino group between 
$1023.15 \mathrm{~cm}^{-1}$ and $1259.99 \mathrm{~cm}^{-1}$ (carapace), $1022.58 \mathrm{~cm}^{-1}$ and $1260.30 \mathrm{~cm}^{-1}$ (claw) and $1022.41 \mathrm{~cm}^{-1}$ and $1260.20 \mathrm{~cm}^{-1}$ (legs). When the peak at $1384 \mathrm{~cm}^{-1}$ represents the $-\mathrm{C}-\mathrm{O}$ stretching of primary alcoholic group $\left(-\mathrm{CH}_{2}-\mathrm{OH}\right)$. The primary alcoholic group represented by a band in $1378.54 \mathrm{~cm}^{-1}$ (carapace), $1380.14 \mathrm{~cm}^{-1}$ (claw) and 1379.92 $\mathrm{cm}^{-1}$ (legs) respectively.

The chitin and chitosan are used in the preparation of the materials like wound dressing, antibacterial and antifungal agents, dialysis membrane, biomedical beads, fabrics and gauzes (Subashinghe, 1999). Chitosan is as a wound-healing accelerator, and its effectiveness in protecting wound from bacterial invasion by suppressing bacterial proliferation. It may act effectively against typhoid producing micro organisms (Yadav and Bhise, 2004).

It is interesting to note that inspite of the considerable progress in chitin / chitosan research and the large number of potential application of chitosan and its derivatives, their commercial applications are somewhat limited. Hence, it could be safely assumed that at the present level of industrial usage of chitin / chitosan, the shrimp and crab processing industries world over would be capable of satisfying the raw material requirements for decades to come.

The slow growth of the industry has been attributed by some to the negative role of patents, which have tended to show down market development. It is also believed that instead of examining ways of using chitin / chitosan as a substitute for ingredients already in usage in agriculture and industry. More research on identifying specific uses and the advantages would help expand the spectrum.

\section{ACKNOWLEDGEMENT}

The authors are thankful to Ocean Science and Technology Cell, Department of Ocean Development (Government of India) for providing the financial support.

\section{REFERENCES}

[1] Brzerki, M.M.1987. Chitin and chitosan-putting waste to good use. Infofish International. Vol.5. pp.31-33.

[2] Das, N.G, P.A. Khan and Z. Hossain, 1996. Chitin from the shell of two coastal portunid crabs of Bangladesh. Indian.J.Fish. 43(4): 413-415.

[3] Krishnamoorthy, P., A. Gokul, P. Thirumala and M. Kathirvel, 2003. Commercially important crabs of India - A pictorial guide for their identification. Training manual faunal diversity of India (ZSI). pp.197-203.

[4] Nair, K.G.R. and P. Madhavan, 1989. Advances in chitin research. In: Recent trends in Processing Low Cost Fish. K. Balachandran et al (Ed). Society of Fisheries Technologists. India. 174pp.

[5] Parasakthi, M.S., 2004. Extraction of chitin from two cephalopods. M.Sc., Dissertation, Annmali University, India. p.18.

[6] Patel., Y.T and S.B. Sadam, 2002. Chitin\&chitosan treasure from crustacean shell waste. Seafood Export Journal. Vol. XXXIII. No.7.pp.31-38.

[7] Saraswathy, G., S. Pal, C. Rose and T.P. Sastry, 2001. A novel bio-inorganic bone important containing deglued bone, chitosan and gelatin. Bull.Mater.Sci., 24(4):415-420.

[8] Shigemasa $Y, H$. Matsuura, H. Sashwa and H. Saimoto, 1996. Evaluation of different ratios from infrared spectroscopy for analyzing the degree of deacetylation in chitin. Intl. J. Biol.Macromolecules. 18: $237-242$.

[9] Subasinghe, S.,1999. Chitin from shellfish wastehealth benefits over-shadowing industrial areas. Infofish International,3/99: 58-65.

[10] Takigucji, Y., 1991a. Preparation of chitin. In: A. Otakara and M.Yabuki (eds.)chitin, chitosan Jikken manual chapter 1, Gihodou Shupan Kabushki Kaisha, Japan 1-7.

[11] Takigucji, Y., 1991b. Preparation of chitosan and partially deacetylated chitin. In: A. Otakara and M.Yabuki (eds.)chitin, chitosan Jikken manual chapter 2, Gihodou Shupan Kabushki Kaisha, Japan 9-17.

[12] Udgata, S.K. and B.K.Khuntia. 1994. Chitin and chitosan - the promising shell utilization. Seafood Export Journal, pp.5-8.

[13] Varghese, K.G.J.P, 2002. Studies on the stomatopod Harpiosquilla melanoura Manning, 1968 (Crustacea:Stomatopoda). Ph.D.Thesis, Annamalai University, India. p.150.

[14] Yadav, A.V. and S.B. Bhise, 2004. Chitosan: A potential biomaterial effective against typhoid. Curr. Sci., Vol.87, No.9: 1176-1178.

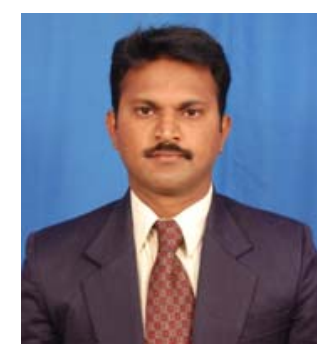

Mr. N.Thirunavukkarasu is the Head in-charge of the Department of Marine Studies and Coastal Resource Management, Madras Christian College (Autonomous), Tambram, Chennai. He obtained his Ph.D from CAS in Marine Biology, Annamalai University. 